\title{
PERLINDUNGAN TERHADAP ANAK YANG BEKERJA MEMBANTU ORANG TUANYA SEBAGAI NELAYAN MENURUT HUKUM INTERNASIONAL DAN IMPLEMENTASINYA DI INDONESIA
}

\author{
Widya Krulinasari \\ Universitas Lampung \\ Email : krudick_hi@yahoo.com
}

\begin{abstract}
Abstrak
Indonesia sebagai Negara kepulauan dan salah satunya didukung oleh jumlah nelayan menjadikan Indonesia sebagai 298egara kepulauan terbesar di dunia. Kondisi yang ada saat ini adalah kesejahteraan sosial yang memburuk di kalangan nelayan. Hal itu membuat tersendat-sendatnya pemenuhan kebutuhan pendidikan anak-anaknya merupakan salah satu faktor anak nelayan putus sekolah bekerja untuk membantu ekonomi keluarga. Permasalahan yang timbul adalah Bagaimana perlindungan terhadap anak yang bekerja membantu orang tuanya sebagai nelayan menurut hukum internasional dan implementasinya di Indonesia.

Perlindungan terhadap anak yang bekerja membantu orang tuanya sebagai nelayan menurut Hukum Internasional diatur dalam Pasal 22 Deklarasi Hak Asasi Manusia Tahun 1948, Konvensi ILO No.138 yaitu batas umur dikatakan dewasa 15 tahun, dan dalam Pasal 28, Pasal 29, Pasal 31 (1) (2) dan Pasal 32 (1) Konvensi Hak Anak Tahun 1989. Sementara Implementasi Perlindungan terhadap anak yang bekerja membantu orang tuanya sebagai nelayan di Indonesia diatur dalam Undang-Undang Perlindungan Anak Pasal 9, Pasal 11 dan Pasal 59 yang menyatakan bahwa yang disebut sebagai anak adalah orang yang berusia di bawah 18 tahun dan atau belum menikah. Selain itu pula pemerintah dan lembaga negara yaitu Komisi Perlindungan Anak Indonesia (KPAI) yang memberikan perlindungan terhadap anak salah satunya adalah yang dikategorikan ke dalam bentuk buruh/ pekerja anak yaitu mancari ikan di lepas pantai seperti jermal. Yang dalam hal ini bisa disamakan dengan anak yang bekerja membantu orang tuanya sebagai nelayan.
\end{abstract}

Kata Kunci : Pelindungan Anak, Hukum Internasional dan Implementasi

\begin{abstract}
Indonesia as an archipelago country and one of them is supported by the number of fishermen making Indonesia as the largest archipelago in the world. The current condition is the worsening social welfare among fishermen. This makes the staggering fulfillment of the educational needs of his children is one of the factors of children dropping out of school to work to help the family economy. The problems that arise are how the protection of children working to help their parents as fishermen according to international law and its implementation in Indonesia.
\end{abstract}


The protection of working children assisting their parents as fishermen under International Law is governed by Article 22 of the 1948 Declaration of Human Rights, ILO Convention No.138, namely the age limit is said to be 15 years of age, and in Article 28, Article 29, Article 31 (1) (2) and Article 32 (1) of the Convention on the Rights of the Child in 1989. While the Implementation of Protection of working children assisting their parents as fishermen in Indonesia is regulated in the Child Protection Act Article 9, Article 11 and Article 59 stating that the so- the child is a person under the age of 18 and / or unmarried. In addition, the government and state institutions, namely the Indonesian Child Protection Commission (KPAI) which provides protection for children one of which is categorized into the form of labor / child labor that mancari fish offshore like jermal. Which in this case can be likened to children who work to help their parents as fishermen.

Keywords: Child Protection, International Law and Implementation

\section{Pendahuluan}

Konvensi Perserikatan Bangsa-Bangsa tentang Hukum Laut atau dikenal dengan sebutan KHL 1982 membedakan negara (dari aspek geografi) menjadi tiga yaitu, Negara Tak Berpantai, Negara Pantai, dan Negara Kepulauan. ${ }^{1}$ Indonesia sebagai salah satu negara kepulauan telah mendaftarkan 2.590 pulau bernama dan berkoordinat kepada Perserikatan Bangsa-Bangsa (PBB) melalui forum United Nations Conference on the Standardization of Geographical Names (UNCSGN) dan United Nations Groups of Expert on Geographical Names (UNGEGN), pada tanggal 7-18 Agustus 2017 di New York Amerika Serikat. ${ }^{2}$ Sehingga jumlah pulau di Indonesia yang telah didaftarkan sebanyak 16.056 pulau bernama dan berkoordinat.

Indonesia sebagai Negara kepulauan dan salah satunya didukung oleh jumlah nelayan menjadikan Indonesia sebagai negara kepulauan terbesar di dunia. Kondisi

\footnotetext{
1 Abdul Muthalib Tahar, Zona-zona Maritim Berdasarkan Konvensi Hukum Laut 1982 dan Perkembangan Hukum Laut Indonesia, Universitas Lampung, 2015, Hal.15.

${ }^{2}$ Tribuntravel.com hari senin tanggal 21 Agustus 2017 pukul 20:17 WIB .
} 
yang ada saat ini adalah kesejahteraan sosial yang memburuk di kalangan nelayan sangat dirasakan di desa-desa pesisir yang perairannya mengalami overfishing (tangkap lebih) sehingga hasil tangkap atau pendapatan yang diperoleh nelayan bersifat fluktuatif, tidak pasti, dan semakin menurun dari waktu ke waktu. Dalam situasi demikian, rumah tangga nelayan akan senantiasa berhadapan dengan tiga persoalan yang sangat krusial dalam kehidupan nelayan, yaitu (1) pergulatan untuk memenuhi kebutuhan hidup sehari-hari, (2) tersendat-sendatnya pemenuhan kebutuhan pendidikan anak-anaknya, dan (3) terbatasnya akses mereka terhadap jaminan kesehatan. ${ }^{3}$

Dari Persoalan kedua di atas, dengan tersendat-sendatnya pemenuhan kebutuhan pendidikan anak-anaknya merupakan salah satu faktor anak nelayan putus sekolah bekerja untuk membantu ekonomi keluarga. Berdasarkan penelitian ${ }^{4}$ banyak anak nelayang putus sekolah bekerja untuk membantu perekonomian keluarga di Desa Muara Gading Mas Kecamatan Labuhan Maringgai Lampung Timur Propinsi Lampung.

Berdasarkan latar belakang masalah di atas penulis mengambil dua permasalahan yang akan dikaji, yaitu :

a. Bagaimana Perlindungan Terhadap Anak Yang bekerja Membantu Orang Tuanya sebagai nelayan menurut Hukum Internasional?

\footnotetext{
${ }^{3}$ Kusnadi, Jaminan Sosial Nelayan, PT.LKIS Pelangi Aksara, 2007, Hal.2.

4 Arsuli, Abstrak Skripsi, Faktor-faktor Penyebab Anak Nelayan Putus Sekolah Bekerja Untuk Membantu Ekonomi Keluarga Di Desa Muara Gading Mas Kecamatan Labuhan Maringgai Kabupaten Lampung Timur, Universitas Lampung.
} 
b. Bagaimana Implementasi Perlindungan Terhadap Anak Yang bekerja Membantu Orang Tuanya sebagai nelayan di Indonesia?

\section{Pembahasan}

\section{Perlindungan Terhadap Anak Yang bekerja Membantu Orang Tuanya Sebagai Nelayan Menurut Hukum Internasional}

Manusia diciptakan oleh Tuhan Yang Maha Esa dengan seperangkat hak yang menjamin derajatnya sebagai manusia. Hak-hak inilah yang kemudian disebut dengan HAM, yaitu hak yang diperoleh sejak kelahirannya sebagai manusia yang merupakan karunia Sang Pencipta. ${ }^{5}$ Dalam Pembukaan Deklarasi Universal Hak Asasi Manusia yang diadopsi pada 10 Desember menentukan bahwa "Pengakuan Martabat bawaan dan hak-hak yang sama dan mutlak pada semua umat manusia adalah dasar dari kemerdekaan, keadilan, dan perdamaian dunia”. Meski arti penting hak asasi manusia dalam struktur Internasional telah diakui secara umum, terdapat banyak kebingungan mengenai hakikat dengan perannya dalam Hukum Internasional. ${ }^{6}$

Pasal 22 Deklarasi Hak Asasi Manusia menyatakan bahwa Hak untuk mendapatkan jaminan sosial dan terwujudnya hak-hak ekonomi, sosial, dan budaya. Atas dasar Pasal tersebut dapat disimpulkan bahwa setiap manusia mempunyai hak atas ekonomi ${ }^{7}$. Namun berkaitan dengan Hak Anak, ada aturan sendiri yaitu dalam Konvensi Hak Anak Tahun 1989 adalah salah satu instrumen internasional di bidang

${ }^{5}$ Budiyono, Kebebasan Beragama Dalam Dokumen Hak Asasi Manusia Internasional dalam Dimensi Hukum Internasional Seri Monograf Volume 2 Tahun 2014, Kerjasama Pusat Kajian Konstitusi dan Peraturan Perundang-undangan (PKKPUU) \& Bagian Hukum Internasional Fakultas Hukum Universitas Lampung, Hal.57.

${ }^{6}$ Malcolm N. Shaw QC, Hukum Internasional, Edisi Ke 6, .Nusamedia, Bandung, 2013, Hal.261.

${ }^{7}$ Deklarasi Hak Asasi Manusia Tahun 1948. 
hak asasi manusia yang secara khusus mengatur segala sesuatu tentang hak anak. ${ }^{8}$ Konvensi ini diadopsi (disetujui) oleh Majelis Umum Perserikatan Bangsa-Bangsa (PBB) pada 20 November 1989 melalui resolusi 44/25 tertanggal 20 Novenber dan sesuai ketentuan Pasal 49 (1) mulai berlaku pada 2 September 1990.

Anak dalam Konvensi ini adalah pemegang hak-hak dasar dan kebebasan sekaligus sebagai pihak yang menerima perlindungan khusus. ${ }^{9}$ Memasuki Abad 21, kondisi anak-anak di dunia masih tetap memprihatinkan. UNICEF (United Nation Children Fund), misalnya dalam laporan mengenai keadaan anak-anak di dunia tahun 2000 di antaranya memperkirakan : 130 juta anak usia sekolah di negara berkembang tidak memiliki akses terhadap pendidikan dasar, 250 juta anak di negara berkembang bekerja dalam lingkungan yang berbahaya dan ekspolitatif, dan sekitar 250 juta anak di dunia hidup dalam situasi yang berbahaya dan genting. ${ }^{10}$

Secara lebih rinci ada beberapa kelompok-kelompok anak yang teridentifikasi yang berada dalam kondisi yang tidak menguntungkan yaitu Anak-anak di pedesaan; Anak-anak jalanan dan daerah kumuh perkotaan; Anak Perempuan; pekerja anak; pelacuran anak; anak-anak cacat; anak-anak pengungsi dan tidak berkewarganegaraan; anak-anak dalam penjara; anak-anak korban kekerasan dan terlantar. $^{11}$

\footnotetext{
${ }^{8}$ Konvensi Hak Anak 20 November 1989.

${ }^{9}$ Marta Santos Pais, "The United Nations Convention on the Rights of the Child", dalam bulletin of Human Rights 91/2 (Geneva : United Nations, 1992), Hal.75.

${ }^{10}$ Center For Human Right, The right of the child (Fact sheet No.10) Geneva: United Nations, 2012, Hal.2.

${ }_{11}$ Candra Gautama, Konvensi Hak Anak; Panduan bagi Jurnalis, Lembaga Studi Pers dan Pembangunan (LSPP), Jakarta, 2000, Hal.6-11.
} 
Khusus untuk pekerja anak, meskipun eksploitasi ekonomi terhadap anakanak telah dilarang, praktik ini masih banyak terjadi di sebagian negara berkembang usia kerja minimum ditetapkan antara usia 12 hingga 13 tahun, lebih rendah dari ketetapan yang tercantum dalam Konvensi ILO (International Labour of Organizations) No.138, yaitu 15 Tahun. ${ }^{12}$ Selain itu juga 70 persen penduduk di dunia termasuk anak-anak tinggal di pedesaan. Mereka seringkali tidak memiliki akses yang cukup terhadap pelayanan, sumber daya dan infrastruktur yang bisa membantu mengembangkan seluruh potensi mereka.

Tekanan ekonomi yang berat mendorong anak-anak untuk bekerja. Kondisi sosial-ekonomi ini telah merampas kesempatan mereka untuk terlibat dalam berbagai kegiatan yang sangat dibutuhkan anak-anak terutama pendidikan dan rekreasi. ${ }^{13}$ Hal tersebut sesuai dengan yang diatur dalam Pasal 28 dan Pasal 29 Konvensi Hak Anak 1989 untuk jaminan pendidikan, Pasal 31 (1) dan (2) Konvensi Hak Anak 1989 Untuk jaminan beristirahat dan bersenang senang.

Khusus untuk mencegah eksploitasi ekonomi terhadap anak dalam Konvensi ini diatur pada Pasal 32 (1). Yang berbunyi "Negara-negara pihak mengakui hak anak untuk dilindungi dari eksploitasi ekonomi dan dari melakukan setiap pekerjaan yang mungkin berbahaya atau mengganggu pendidikan si anak, atau membahayakan kesehatan si anak atau pengembangan fisik, mental, spiritual, moral, dan sosialnya.

${ }^{12}$ Candra Gautama, Op.Cit, Hal.8

${ }^{13} \mathrm{Ibid}$, Hal.6-7 
Berkaitan dengan anak yang bekerja membantu orang tuanya sebagai nelayan dalam menangkap ikan di wilayah laut, anak-anak tersebut pasti tinggal di wilayah pedesaan sebagaimana yang disebutkan dalam kelompok-kelompok anak yang teridentifikasi ke dalam kondisi yang tidak menguntungkan. Hal ini sudah dapat dipastikan melanggar apa yang diatur dalam Konvensi ILO No.38 yaitu usia kerja anak adalah di bawah 15 tahun. Artinya bagi anak-anak nelayan yang usianya belum 15 tahun tidak diperbolehkan untuk bekerja sekalipun itu hanya membantu orang tuanya sebagai nelayan misalkan dalam hal meangkap ikan, menjual ataupun segala macam bentuk kegiatan yang mempunyai nilai ekonomi.

Selain itu pula dalam Deklarasi Hak Asasi Manusia Konvensi Hak Anak 1989 dinyatakan bahwa anak-anak itu berhak untuk mendapatkan pendidikan dan hiburan serta rekreasi. Dari latar belakang tulisan ini dapat dilihat bahwa apa yang terjadi di Desa Muara Gading Mas Kecamatan Labuhan Maringgai Lampung Timur Propinsi Lampung, dimana anak-anak nelayan memilih untuk putus sekolah bahkan tidak sekolah dengan tujuan membantu orang tuanya sebagai nelayan, dalam hal ini sudah melanggar apa yang diatur dalam Konvensi Hak Anak 1989.

Anak yang membantu orang tuanya bekerja sebagai nelayan baik itu atas kemauan sendiri ataupun karena tuntutan orang tua dalam hal ini jelas akan mengurangi hak mereka sebagai anak yaitu hak pendidikan, hiburan dan rekreasi. Selain itu pula dengan memperbolehkan anaknya membantu pekerjaan terebut berarti sudah mengeksploitasi anak tersebut secara ekonomi. Hal-hal tersebut jelas melanggar apa yang diatur dalam Konvensi Hak Anak 1989. 


\section{Implementasi Perlindungan Terhadap Anak Yang bekerja Membantu Orang}

\section{Tuanya sebagai nelayan di Indonesia}

Indonesia telah meratifikasi Konvensi Hak Anak pada 5 September 1990 melalui Kepres No.36 Tahun 1990 sebelumnya Indonesia telah menandatangani Konvensi ini pada 26 Januari 1990. Untuk Masalah Anak, di Indonesia ada Undangundang No.23 Tahun 2002 Tentang Perlindungan anak (UUPA). Pada Undangundang ini disebutkan pengertian anak yaitu berusia 18 Tahun termasuk anak dalam kandungan juga yang sudah menikah. Dalam Undang-Undang ini dijelaskan bahwa penyelenggaraan perlindungan anak adalah orang tua, pemerintah dan negara.

Undang-undang ini melingkupi semua aspek tentang hak anak dan beberapa di antaranya adalah hak identitas, hak atas kesehatan, hak atas pendidikan dan hak atas perlindungan. Perlindungan anak meliputi perlindungan terhadap kekerasan, eksploitasi, diskriminasi dan penelantaran. ${ }^{14}$ Pada Pasal Pasal 9 mengatur Hak Pendidikan dan Pengajaran, selain itu pada Pasal 11 UUPA diatur Hak anak yang salah satunya adalah Hak rekreasi.

Pada Bagian kelima Pasal 59 UUPA mengatur Perlindungan Khusus yaitu Pemerintah dan lembaga negara lainnya berkewajiban dan bertanggung jawab untuk memberikan perlindungan khusus pada salah satunya kepada anak tereksploitasi secara ekonomi dan atau seksual.

Komisi Perlindungan Anak Indonesia (KPAI) adalah lembaga yang diamanatkan UU No.23 Tahun 2003 tentang Perlindungan Anak, bertugas menerima

\footnotetext{
${ }^{14}$ Undang-Undang No.23 Tahun 2002 Tentang Perlindungan anak
} 
pengaduan masyarakat yang berkaitan dengan perlindungan anak. Pada sisi lain juga perlindungan terhadap anak yang terlibat tindak pidana pelanggaran hukum sering diperlakukan seperti orang dewasa. Berbagai masalah perlindungan anak yang terjadi di Indonesia dapat dilihat dari berbagai bidang perlindungan anak, diantaranya : Bidang Hak Sipil dan Kebebasan; Bidang keluarga dan pengasuhan alternatif; Bidang Kesehatan dan Kesejahteraan Dasar; Bidang pendidikan, rekreasi dan aktivitas budaya; Bidang perlindungan khusus (program Anak berhadapan dengan Hukum, Pornografi, traficking). ${ }^{15}$

Berkaitan dengan anak yang bekerja membantu orang tuanya sebagai nelayan menurut UUPA No.23 Tahun 2002 salah satu permasalahan dalam perlindungan khusus terhadap anak dimana dalam hal ini anak dikategorikan ke dalam bentuk buruh/ pekerja anak yaitu mancari ikan di lepas pantai seperti jermal.

Dari urain tersebut terlihat jelas bahwa yang dikatakan anak adalah setiap orang yang berusia di bawah 18 tahun dan atau belum menikah berhak memperoleh hak untuk pendidikan dan rekreasi serta memperoleh perlindungan khusus, termasuk anak-anak yang membantu orang tua yang bekerja sebagai nelayan.

\section{Kesimpulan}

${ }^{15}$ www.kpai.go.id diakses pada tanggal 1 Oktober 2017 pukul 00.19 Wib 
Dari uraian di atas dapat disimpulkan bahwa, Perlindungan terhadap anak yang bekerja membantu orang tuanya sebagai nelayan menurut Hukum Internasional diatur dalam Pasal 22 Deklarasi Hak Asasi Manusia Tahun 1948, Konvensi ILO No.138 yaitu batas umur dikatakan dewasa 15 tahun, dan dalam Pasal 28, Pasal 29, Pasal 31 (1) (2) dan Pasal 32 (1) Konvensi Hak Anak Tahun 1989.

Implementasi Perlindungan terhadap anak yang bekerja membantu orang tuanya sebagai nelayan di Indonesia diatur dalam Undang-Undang Perlindungan Anak Pasal 9, Pasal 11 dan Pasal 59 yang menyatakan bahwa yang disebut sebagai anak adalah orang yang berusia di bawah 18 tahun dan atau belum menikah. Selain itu pula pemerintah dan lembaga negara yaitu Komisi Perlindungan Anak Indonesia (KPAI) yang memberikan perlindungan terhadap anak salah satunya adalah yang dikategorikan ke dalam bentuk buruh/ pekerja anak yaitu mancari ikan di lepas pantai seperti jermal. Yang dalam hal ini bisa disamakan dengan anak yang bekerja membantu orang tuanya sebagai nelayan.

\section{Daftar Pustaka}

Gautama, Candra, Konvensi Hak Anak; Panduan bagi Jurnalis, Lembaga Studi Pers dan Pembangunan (LSPP), Jakarta, 2000.

Kusnadi, Jaminan Sosial Nelayan, PT.LKIS Pelangi Aksara, 2007.

Muthalib Thahar, Abdul. Zona-zona Maritim Berdasarkan Konvensi Hukum Laut 1982 dan Perkembangan Hukum Laut Indonesia, Universitas Lampung, 2015.

N. Shaw QC, Malcolm, Hukum Internasional, Edisi Ke 6, .Nusamedia, Bandung, 2013. 
Pais Santos, Marta, "The United Nations Convention on the Rights of the Child", dalam bulletin of Human Rights 91/2 (Geneva : United Nations, 1992).Konvensi Hak Anak 20 November 1989.

Arsuli, Abstrak Skripsi, Faktor-faktor Penyebab Anak Nelayan Putus Sekolah Bekerja Untuk Membantu Ekonomi Keluarga Di Desa Muara Gading Mas Kecamatan Labuhan Maringgai Kabupaten Lampung Timur, Universitas Lampung.

Budiyono, Kebebasan Beragama Dalam Dokumen Hak Asasi Manusia Internasional dalam Dimensi Hukum Internasional Seri Monograf Volume 2 Tahun 2014, Kerjasama Pusat Kajian Konstitusi dan Peraturan Perundang-undangan (PKKPUU) \& Bagian Hukum Internasional Fakultas Hukum Universitas Lampung.

Center For Human Right, The right of the child (Fact sheet No.10) Geneva: United Nations, 2012.

Deklarasi Hak Asasi Manusia Tahun 1948

Konvensi Hak Anak Tahun 1989

Konvensi ILO

Undang-Undang No.23 Tahun 2002 Tentang Perlindungan anak

www.kpai.go.id

Tribuntravel.com 